\title{
STUDIES OF STREPTOCOCCAL FIBRINOLYSIS. I. THE DISSIMI- LARITY OF SERUM PROTEASE AND TRYPSIN AS INDICATED BY THE SEPARATE SPECIFICITIES OF THEIR KINASES, FIBRINOLYSIN AND ENTEROKINASE ${ }^{1}$
}

\author{
By MELVIN H. KAPLAN \\ (From the Respiratory Diseases Commission Laboratory, Regional Station Hospital, Section 2, \\ Fort Bragg, North Carolina)
}

(Received for publication September 5, 1945)

It was first observed in 1933 that culture filtrates of $\beta$-hemolytic streptococci were capable of lysing human fibrin clots (1). The active agent, termed fibrinolysin, showed no effect on proteins other than fibrin, and only slight effect on the fibrin of animal species (2). Although extensive investigation of the chemical, bacteriological, and immunological aspects of this phenomenon followed, the underlying mechanism of the reaction remained little understood. However, in 1938, the observation was made that streptococcal fibrinolysis occurred only in the presence of an accessory plasma component (3). This substance, apparently deficient in some species, was termed lytic factor.

In a previous report (4), it was shown that the lytic factor was similar in properties to the serum protease, an enzyme which occurs regularly in an inactive state in normal blood $(5,6)$. Like the serum protease, the lytic factor was associated with the serum euglobulin fraction. Preparations of the lytic factor and the inactive protease could be activated by treatment with chloroform with the production of comparable amounts of proteolytic activity. This same activation reaction occurred almost instantaneously in the presence of fibrinolysin $(7,4)$. Thus, the function of fibrinolysin in streptococcal fibrinolysis was the conversion of the lytic factor into the active protease.

The transformation of the lytic factor into the serum protease by fibrinolysin is in essential agree-

1 This investigation was supported through the Commission on Acute Respiratory Diseases, Board for the Investigation and Control of Influenza and Other Epidemic Diseases in the Army, Preventive Medicine Service, Office of the Surgeon General, United States Army, and by grants from the Commonwealth Fund, the W. K. Kellogg Foundation, the John and Mary R. Markle Foundation and the International Health Division of the Rockefeller Foundation to the Board for the Investigation and Control of Influenza and Other Epidemic Diseases for the Commission on Acute Respiratory Diseases. ment with catalytic monomolecular theory (8). Fibrinolysin is thus a kinase, and the fibrinolysin reaction may be regarded as analogous to the transformation of trypsinogen into trypsin by enterokinase (9).

The present report is an extension of previous studies on the nature of the lytic agent in streptococcal fibrinolysis (4). The striking parallelism between the activation of the lytic factor and trypsinogen is but one aspect of the close similarity of these two enzymes. Serum protease and trypsin have been found to be similar with respect to the following properties: activity at alkaline $\mathrm{pH}(10$, $11)$, inhibition by animal and plant antiproteases $(12,8)$, clotting effect on normal and hemophilic blood $(13,14,6)$ and inhibition by heparin $(15$ to 17). Several studies have referred to the blood enzyme as serum tryptase $(5,18)$, or even as plasma trypsin $(17,19,20)$, and in several instances, consideration has been given to the proposition that the protease and trypsin may be identical.

In the present report, it is demonstrated that serum protease and trypsin are not identical. Evidence for the dissimilarity of the two enzymes is based upon the separate specificities of their activators, fibrinolysin and enterokinase. In addition, it is shown that neutralizing antibodies to fibrinolysin are without effect on enterokinase. A recent independent study (8) has also suggested differences in the two enzymes as indicated by reaction with inhibitors and extent of hydrolysis of casein. It may be concluded from these observations that the two proteolytic enzymes are different. ${ }^{2}$

\footnotetext{
2 Evidence that the normal protease is distinct from pancreatic trypsin has raised the question of an adequate nomenclature for this enzyme system (8). It is agreed that the present usage of the terms, serum protease for the active enzyme, and lytic factor for the zymogen form, is not without objection. However, it is believed that the sug-
} 


\section{MATERIALS AND METHODS}

1. Fibrinolysin. The source of fibrinolysin was a highly active fibrinolytic strain (No. 98) of group A $\beta$-hemolytic streptococcus isolated from the blood of a patient with erysipelas. It was not successfully typed by means of 37 available Lancefield typing $\operatorname{sera}^{3}$ (23). Fibrinolysin was obtained by alcoholic precipitation (2) from the Seitz filtrate of an 18-hour culture in beef-heart infusion broth containing 0.05 per cent added dextrose. The precipitated fibrinolysin was redissolved in a volume of buffered saline one-half that of the original filtrate, and then dispensed in $5 \mathrm{ml}$. lots into small ampules. These ampules were either dried by the lyophile process or stored in the frozen state at $-70^{\circ} \mathrm{C}$. Both methods of storage yielded highly stable and completely soluble products.

2. Fibrinogen. The product employed was a lyophilized preparation of human fibrinogen, 4 Fraction I (24), separated from pooled plasma by alcoholic fractionation. The fibrinogen solution used contained 0.09 per cent fibrinogen in buffered saline ( 0.30 gram Fraction I per $100 \mathrm{ml}$. of buffer). Clots formed from this fibrinogen preparation were readily lysed by fibrinolysin, indicating that the preparation contained lytic factor in adequate amount.

3. Thrombin. The thrombin preparation was a 1:10 dilution of a clotting globulin ${ }^{5}$ prepared from rabbit blood.

4. Lytic factor. The method used for the preparation of lytic factor was essentially that described by Milstone (3). The precipitate obtained after dilution of serum with 19 volumes of distilled water and acidification to $\mathrm{pH} 5.5$ was finally dissolved in a volume of buffered saline, $\mathrm{pH}$

gested terms, plasmin and plasminogen, which emphasize the plasma source of the protease, should not be adopted until the normal protease is differentiated from other proteases which may be found in human and animal plasmas $(21,22,5)$. A suitable alternative is the more conservative nomenclature; serum tryptase and serum tryptogen, which has been employed previously $(5,18)$, and which does not imply identity with the trypsin system. On grounds of accuracy, the use of the term streptokinase for fibrinolysin merits support. It has not been employed in the present series of studies because of the firmly established position of the term fibrinolysin in the literature of streptococcal infection, with which the studies from this laboratory have been essentially concerned.

3 Type specific rabbit sera were supplied through the generosity of Drs. Homer T. Swift and Rebecca C. Lancefield.

4 The preparation of Fraction I was obtained through the courtesy of Drs. E. J. Cohn, J. T. Edsall, and S. Howard Armstrong, Jr. It was prepared by the Department of Physical Chemistry, Harvard Medical School, Boston, Mass., from blood collected by the American Red Cross, under a contract, recommended by the Committee on Medical Research, between the Office of Scientific Research and Development and Harvard University.

5 Hemostatic Globulin, Lederle Laboratories, Inc.
7.4 , equal to one-fourth that of the original volume of serum.

5. Trypsinogen. ${ }^{6}$ The preparation of trypsinogen was a partially purified product in the form of an ammonium sulfate filter cake which contained about 50 per cent ammonium sulfate. The solution of trypsinogen employed contained $1.0 \mathrm{mgm}$. per $\mathrm{ml}$. in $0.005 \mathrm{~N} \mathrm{HCl}$.

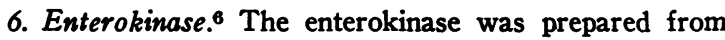
pig duodenal contents and was obtained as an ammonium sulfate filter cake. Solutions of enterokinase were made in buffered saline at the desired concentration. It was found that $0.5 \mathrm{mgm}$. of enterokinase activated completely $1.0 \mathrm{ml}$. of the above trypsinogen solution in 30 minutes at $37^{\circ} \mathrm{C}$.

7. Buffered saline. The buffered saline was a solution of $0.01 \mathrm{M}$ phosphate in 0.85 per cent sodium chloride at $\mathrm{pH} 7.4$.

8. Measurement of proteolytic activity. For the determination of proteolytic activity, three substrates were used: fibrin, gelatin, and hemoglobin.

a. Fibrin method. The fibrin substrate was a standard fibrinogen-thrombin clot in which was incorporated the mixture to be tested. Assays of the amount of proteolytic activity were made by diluting serially the test material with buffer in $1.0 \mathrm{ml}$. volumes. To $1.0 \mathrm{ml}$. of each dilution were added $1.0 \mathrm{ml}$. of fibrinogen solution, and 0.2 $\mathrm{ml}$. of thrombin. Clotting occurred within 2 minutes. The tubes were incubated for 12 hours in a water bath at $37^{\circ} \mathrm{C}$. At the end of this period, the tubes were read for the highest dilution of test mixture which completely lysed the fibrin clot.

b. Gelatin method. Gelatin liquefaction was measured viscosimetrically with Ostwald viscosity tubes in a constant temperature bath of $37.5^{\circ} \mathrm{C}$. The gelatin was a 3 per cent solution in 1/20 M phosphate buffer, $\mathrm{pH} 7.4$, and contained thymol as a bacteriostatic agent. The following procedure was employed:

Four ml. of gelatin were mixed with $2.0 \mathrm{ml}$. of the test preparation, and $5.0 \mathrm{ml}$. of this mixture were immediately transferred to a viscosity tube. The temperature of the reagents was adjusted to $37.5^{\circ}$ before mixing. Viscosity efflux times at $37.5^{\circ}$ were determined at 20 -minute intervals. The amount of proteolytic activity was then measured by the percentage of decrease in the efflux time of the substrate-enzyme mixture. The initial efflux time was-determined by extrapolation to zero time.

c. Hemoglobin method. The hydrolysis of hemoglobin was measured by the liberation of tyrosine and tryptophane as determined colorimetrically by the method of Folin and Ciocalteu (25) as modified by Anson (26). The hemoglobin substrate was a 2.2 per cent solution buffered by $0.1 \mathrm{M}$ phosphate at $\mathrm{pH} 7.5$. The color value of the digestion filtrate was read in terms of $\mathbf{m g m}$. of pure tyrosine as determined from a calibration curve.

6 The preparations of trypsinogen and enterokinase were obtained through the courtesy of Dr. J. N. Northrop and Dr. M. Kunitz. 


\section{EXPERIMENTAL}

\section{Attempted activation of serum protease by entero- kinase}

Activation of serum protease was attempted by the addition of varying amounts of enterokinase to solutions of lytic factor. The activation mixtures contained $1.0 \mathrm{ml}$. of lytic factor and $1.0 \mathrm{ml}$. of a given enterokinase solution in buffer at $\mathrm{pH}$ 7.4. After incubating these mixtures for $0,1,2$, and 4 hours at $37^{\circ} \mathrm{C}$., $4.0 \mathrm{ml}$. of gelatin were added, and the amount of proteolytic activity present tested by gelatin liquefaction.

The solutions of enterokinase tested included the following concentrations : $0.5 \mathrm{mgm}$. per $\mathrm{ml}$., $2.0 \mathrm{mgm}$. per $\mathrm{ml}$., and $8.0 \mathrm{mgm}$. per $\mathrm{ml}$. The lowest concentration tested, i.e., $0.5 \mathrm{mgm}$. per ml., was sufficient to effect complete activation of a trypsinogen solution within 30 minutes at $37^{\circ} \mathrm{C}$. Consequently, the range of enterokinase concentration employed was sufficiently wide to test for any possible activation effect on lytic factor. It was found, however, that concentrated enterokinase solutions also possessed appreciable amounts of proteolytic activity, due to the presence of an associated enzyme impurity. Accordingly, it was necessary to run suitable controls to take this factor into account.

The results of these experiments showed that activation of lytic factor did not occur at any of the concentrations of enterokinase tested. A representative experiment is given in Table $I$, in which the enterokinase solution

TABLE I

Attempted activation of serum lytic factor by enterokinase

\begin{tabular}{c|c|c|c|c|c}
\hline \hline No. & \multicolumn{3}{|c|}{ Reaction mixture } & $\begin{array}{c}\text { Proteolytic activity. } \\
\text { Change in relative } \\
\text { viscosity of gela- } \\
\text { tin in 2 hours }\end{array}$ \\
\cline { 2 - 5 } & $\begin{array}{c}\text { Lytic } \\
\text { factor }\end{array}$ & $\begin{array}{c}\text { Entero- } \\
\text { kinase }\end{array}$ & $\begin{array}{c}\text { Fibrino- } \\
\text { lysin }\end{array}$ & Saline & mer cent \\
1 & $\begin{array}{c}\mathrm{ml} . \\
1.0\end{array}$ & $\mathrm{ml}$. & $\mathrm{ml.}$ & $\mathrm{ml.}$ & 1.2 \\
3 & 1.0 & 1.0 & & 1.0 & 0 \\
4 & 1.0 & 1.0 & 1.0 & 1.0 & 1.4 \\
\hline
\end{tabular}

employed contained $0.5 \mathrm{mgm}$. per $\mathrm{ml}$. This amount of enterokinase of itself showed a very slight amount of activity on gelatin; that it did not activate lytic factor, however, is indicated by the fact that after 4 hours at $37^{\circ} \mathrm{C}$., the enterokinase-lytic factor mixtures possessed approximately the same amount of activity as the enterokinase solution alone. This was in marked contrast to the rapid activation of lytic factor by fibrinolysin, shown in the table by the considerable activity of the fibrinolysinlytic factor mixture.

Similar results were obtained using human fibrinogenthrombin clots as substrate. Mixtures of $1.0 \mathrm{ml}$. of enterokinase and $1.0 \mathrm{ml}$. of lytic factor were incubated for 12 hours at $5^{\circ} \mathrm{C}$., before testing by the fibrin method described. In no case was the amount of activity present in the reaction mixtures greater than that possessed by the enterokinase alone. In these experiments then enterokinase did not activate the lytic factor.

\section{Attempted activation of trypsinogen by fibrinolysin}

The transformation of trypsinogen into trypsin in the presence of enterokinase is a typical enzyme reaction catalyzed by enterokinase (9). The activation reaction occurs readily at neutrality, and in this respect is similar to the fibrinolysin reaction. However, trypsinogen also undergoes autocatalytic activation at neutrality. Autocatalysis may be minimized by employing a dilute solution of trypsinogen and by keeping the trypsinogen in acid solution until ready for use. Using the procedure described by Kunitz (9), an attempt was made to activate trypsinogen by means of fibrinolysin.

Reaction mixtures were made up which contained 1.0 $\mathrm{ml}$. of trypsinogen in $0.005 \mathrm{~N} \mathrm{HCl}, 1.0 \mathrm{ml}$. of a concentrated solution of fibrinolysin, and $3.0 \mathrm{ml}$. of $\mathrm{M} / 50$ phosphate buffer, $\mathrm{pH}$ 7.4. Incubation was carried out for 30 minutes at $37^{\circ} \mathrm{C}$. At the end of this period, a $1.0 \mathrm{ml}$. aliquot sample was withdrawn, and immediately tested for proteolytic activity by the hemoglobin method. Since the rate of autocatalytic transformation of trypsinogen to trypsin is appreciable under the conditions of temperature and $\mathrm{pH}$ described, a control was run simultaneously to measure the amount of proteolytic activity autocatalytically produced in 30 minutes. As an additional control, activation of a third trypsinogen solution was simultaneously carried out by the addition of 0.5 mgm. of enterokinase.

TABLE II

Attempted activation of trypsinogen by fibrinolysin

\begin{tabular}{c|c|c|c|c|c}
\hline & \multicolumn{3}{|c|}{ Reaction mixture } & \\
No. & $\begin{array}{c}\text { Tryp- } \\
\text { sinogen }\end{array}$ & $\begin{array}{c}\text { Fibrino- } \\
\text { lysin }\end{array}$ & $\begin{array}{c}\text { Entero- } \\
\text { kinase }\end{array}$ & Buffer & $\begin{array}{c}\text { Proteolytic activity. } \\
\text { Increase in tyrosine }\end{array}$ \\
\cline { 2 - 5 } 1 & $\mathrm{ml.}$ & $\mathrm{ml}$. & $\mathrm{ml}$. & $\mathrm{ml.}$ & mgm. per $100 \mathrm{ml}$. \\
2 & 1.0 & 1.0 & & 3.0 & 1.9 \\
3 & 1.0 & & & 4.0 & 2.0 \\
4 & 1.0 & & 1.0 & 4.0 & 0.1 \\
& & 1.0 & 3.0 & 14.0 \\
\hline
\end{tabular}

The degree of proteolysis (Table II) resulting from the action of the fibrinolysin-trypsinogen mixture was essentially the same as that due to the trypsinogen alone. Thus the amount of trypsin formed in the presence of fibrinolysin may be attributed simply to the autocatalytic activation of the enzyme. This small amount of activity produced autocatalytically, however, was in marked contrast to the proteolytic action resulting from the enterokinase-trypsinogen mixture. The evidence strongly indicated that trypsinogen is not catalytically activated by fibrinolysin, under conditions suitable for the action of enterokinase. 


\section{Effect of antifibrinolysin on enterokinase}

The sera of patients convalescent from infection due to $\beta$-hemolytic streptococci frequently contain antibodies to streptococcal fibrinolysin $(27,1)$, and it is generally accepted that the development of such antibodies is a specific immunological response to streptococcal infection $(28,29)$. In addition, immunochemical studies (30) have indicated that the reaction between fibrinolysin and antifibrinolysin is similar to. the union of toxin and antitoxin in vitro. The reaction may then be regarded as a true antigen-antibody reaction in which the antigen, fibrinolysin, is a kinase.

Since the activities of fibrinolysin and enterokinase are demonstrated under similar physico-chemical conditions, it is possible that their analogous functions are due to structural similarities. In the present experiment, an attempt was made to determine whether evidence of such similarity could be obtained by testing the action of antifibrinolysin on enterokinase. Immunological evidence for the structural similarity of the two kinases might then provide suggestive evidence of the relationship between trypsin and serum protease.

The effect of antifibrinolysin on the activating properties of enterokinase was determined as follows: Progressive dilutions in $1.0 \mathrm{ml}$. volumes were made of an enterokinase solution containing $1.0 \mathrm{mgm}$. per $\mathrm{ml}$. To each dilution was added $0.5 \mathrm{ml}$. of a 1/10 dilution of a convalescent serum which possessed an elevated antifibrinolysin titer. $^{7}$ After incubation for 30 minutes at $37^{\circ} \mathrm{C}$., $1.0 \mathrm{ml}$. of trypsinogen solution was added to each tube, and activation of the trypsinogen allowed to occur for 30 minutes at $37^{\circ} \mathrm{C}$. At the end of this period, 1.0 ml. samples were withdrawn from each mixture and tested for proteolytic activity by the fibrin method. The results thus obtained were compared with a series of controls, in which activation of trypsinogen by the given amounts of enterokinase was allowed to occur in the absence of antifibrinolysin. In these control tests, the trypsinogen and enterokinase mixtures were first incubated for 30 minutes at $37^{\circ} \mathrm{C}$. The serum was added after this period of activation. After these mixtures were incubated for an additional 30 minutes at $37^{\circ} \mathrm{C}$., $1.0 \mathrm{ml}$. aliquots were withdrawn and tested for proteolytic activity. Units of trypsin activity were defined in terms of the reciprocal of the highest dilution of the reaction mixture which completely lysed the standard fibrin clot in 12 hours at $37^{\circ} \mathrm{C}$.

Table III shows that the number of units of trypsin activated in 30 minutes by enterokinase-antifibrinolysin mixtures was no different than the amount of trypsin activated in the absence of antifibrinolysin. As expected, the rate of activation varied with the enterokinase concentration; however, at no concentration was activation inhibited by antifibrinolysin. This failure of the serum to inhibit enterokinase over a wide range of concentration indicates that antifibrinolysin does not combine with en-

7 The titer of antifibrinolysin in the serum was 625 , as determined by the method described in a succeeding paper (31).
TABLE III

Failure of antifibrinolysin to inhibit the enterokinase activation of trypsinogen

\begin{tabular}{|c|c|c|c|c|}
\hline \multicolumn{3}{|c|}{ Reaction mixture } & \multirow{2}{*}{$\begin{array}{l}\text { Units of trypsin* } \\
\text { activated by en- } \\
\text { terokinase previ- } \\
\text { ously incubated } \\
\text { with anti- } \\
\text { fibrinolysin }\end{array}$} & \multirow{2}{*}{$\begin{array}{l}\text { Units of trypsin } \\
\text { activated by } \\
\text { enterokinase in } \\
\text { absence of } \\
\text { antifibrinolysin }\end{array}$} \\
\hline $\begin{array}{l}\text { Entero- } \\
\text { kinase }\end{array}$ & $\begin{array}{l}\text { Serum } \\
\text { anti- } \\
\text { fibrino- } \\
\text { lysin }\end{array}$ & $\begin{array}{l}\text { Tryp- } \\
\text { sinogen }\end{array}$ & & \\
\hline $\begin{array}{c}m g m . p e r \\
m l .\end{array}$ & $m l$. & ml. & & \\
\hline 1.00 & 0.5 & 1.0 & 16 & 16 \\
\hline 0.50 & 0.5 & 1.0 & 16 & 16 \\
\hline 0.25 & 0.5 & 1.0 & 16 & 16 \\
\hline 0.125 & 0.5 & 1.0 & 8 & 8 \\
\hline 0.06 & 0.5 & 1.0 & 4 & 4 \\
\hline 0.03 & 0.5 & 1.0 & 2 & 2 \\
\hline 0 & 0.5 & 1.0 & $<1$ & $<1$ \\
\hline
\end{tabular}

* Units of trypsin is defined in terms of the reciprocal of the highest dilution of the reaction mixture which lysed completely a standard fibrin clot in 12 hours at $37^{\circ} \mathrm{C}$.

terokinase. It is to be concluded that fibrinolysin and enterokinase are probably not closely related in structure.

\section{DISCUSSION}

The similarity between serum protease and trypsin with respect to their physico-chemical properties and their physiological effects has suggested their possible identity. However, recent evidence (8) has suggested certain dissimilarities in the activities of the two enzymes. Both the trypsin-inhibitor in the pancreas and the serum inhibitor were found to exert a proportionately lesser effect on serum protease than on crystalline trypsin; and secondly, crystalline trypsin was capable of hydrolyzing casein after hydrolysis by serum protease had apparently gone to completion.

The present study has provided additional evidence in support of the view that trypsin and serum protease are not identical. The proof of the non-identity of the two enzyme systems is based on the separate and complete specificities of their activators, enterokinase and fibrinolysin. Trypsinogen and lytic factor are catalytically activated under the same physico-chemical conditions. However, the catalytic action of each kinase is specific for its corresponding enzyme system. The different specificities of the two kinases under the same conditions suggest that there are probably structural differences in their enzyme substrates, trypsinogen and lytic factor.

A further indication of the non-identity of tryp- 
sin and serum protease was suggested by the failure of serum which contained specific immunological antibodies to fibrinolysin to inhibit the activity of enterokinase. The exact significance of this observation is difficult to evaluate because of the limited knowledge concerning both the chemical basis of kinase action and the mechanism of immunochemical neutralization. However, in accordance with accepted principles of enzymeand immunochemistry, the neutralization of fibrinolysin, in all probability, may be attributed either (a) to a direct binding of the functional groups of the kinase molecule or (b) to an interference with the activity of such groups (i.e., combination with substrate) as a result, for example, of steric hindrance by antibody molecules.

The failure of antifibrinolysin to neutralize enterokinase may be considered in the light of both of these hypotheses. If the functional groups in the fibrinolysin molecule are antigenically determinant, the failure of antifibrinolysin and enterokinase to react would suggest that the two kinases differ in their functional groups. Accordingly, it would be concluded that lytic factor and trypsinogen are activated by separate catalytic mechanisms, and that the two proteases, therefore, are different. However, if the neutralization of fibrinolysin is the result of steric hindrance by antifibrinolysin antibodies, the failure of antifibrinolysin to combine with enterokinase is indicative only of the fact that both kinases are structurally different. On this basis, it is not possible to conclude that the proteolytic enzymes which are activated are necessarily differrent.

When the evidence is taken as a whole, however, the failure of antifibrinolysin to inhibit enterokinase, and the failure of enterokinase and fibrinolysin to cross react with trypsinogen and serum lytic factor, point strongly to the separate specificities of these proteolytic enzyme systems. It is to be inferred that they are not identical.

\section{SUMMARY}

Evidence is presented that the fibrinolysin-serum protease system differs in specificity from the enterokinase-trypsinogen system. Fibrinolysin does not activate trypsinogen, nor is the serum protease activated by enterokinase. Antibodies to fibrinolysin do not inhibit the enterokinase activation of trypsinogen. The evidence indicates that fibrinolysin and enterokinase are kinases of different structure and of separate specific activities. It is inferred that trypsin and serum protease are not identical.

The author takes pleasure in acknowledging the assistance of Sgt. Curtis Hoover, S/Sgt. Howard E. Duke, T/Sgt. Louis P. Codifer, and Bettie Wooten.

\section{BIBLIOGRAPHY}

1. Tillett, W. S., and Garner, R. L., The fibrinolytic activity of hemolytic streptococci. J. Exper. Med., 1933, 58, 485.

2. Garner, R. L., and Tillett, W. S., Biochemical studies on the fibrinolytic activity of hemolytic streptococci. J. Exper. Med, 1934, 60, 239.

3. Milstone, H., A factor in normal human blood which participates in streptococcal fibrinolysis. J. Immunol., 1941, 42, 109.

4. Kaplan, M. H., Nature and role of the lytic factor in hemolytic streptococcal fibrinolysis. Proc. Soc. Exper. Biol. and Med., 1944, 57, 40.

5. Oppenheimer, C., Die Fermente und ihre Wirkungen, Vol. 2, ed. 5, G. Thieme, Leipzig, 1926.

6. Tagnon, H. J., Davidson, C. S., and Taylor, F. H. L., Studies on blood coagulation: a proteolytic enzyme prepared from calcium and platelet free normal human blood plasma. J. Clin. Invest., 1942, 21, 525.

7. Christensen, L. R., Streptococcal fibrinolysis: a proteolytic reaction due to a serum enzyme activated by streptococcal fibrinolysin. J. Gen. Physiol., 1945, 28, 363.

8. Christensen, L. R., and MacLeod, C. M., A proteolytic enzyme of serum: characterization, activation, and reaction with inhibitors. J. Gen. Physiol., 1945, 28, 559.

9. Kunitz, M., Formation of trypsin from crystalline trypsinogen by means of enterokinase. J. Gen. Physiol., 1939, 22, 429.

10. Northrop, J. H., Crystalline Enzymes. Columbia University Press, New York, 1939.

11. Kaplan, M. H., Tagnon, H. J., Davidson, C. S., and Taylor, F. H. L., Studies on blood coagulation: the nature and properties of a proteolytic enzyme derived from plasma. J. Clin. Invest., 1942, 21, 533.

12. Mirsky, I. A., Inhibition of $\beta$-hemolytic streptococci fibrinolysin by trypsin-inhibitor (antiprotease). Science, 1944, 100, 198.

13. Eagle, H., and Harris, T. N., Studies in blood coagulation. V. The coagulation of blood by proteolytic enzymes (trypsin, papain). J. Gen. Physiol., 1937, $20,543$.

14. Ferguson, J. H., and Erickson, B. N., The coagulant action of crystalline trypsin, cephalin, and lung extracts. Am. J. Physiol., 1939, 126, 661.

15. Horwitt, M. K., Trypsin and chymotrypsin versus heparin. Science, 1945, 101, 376.

16. Glazko, A. J., and Ferguson, J. H., Inhibition of tryp- 
tases by heparin. Proc. Soc. Exper. Biol. and Med., 1940, 45, 43.

17. Rocha e Silva, M., and Andrade, S. O., Antagonism between heparin and plasma trypsin. Science, 1945, $102,670$.

18. Ferguson, J. H., A new blood clotting theory. Science, 1943, 97, 319.

19. Schmitz, A., Uber die Proteinase des Fibrins. Ztschr. f. physiol. Chem., 1936, 244, 89.

20. Iyengar, N. K., Sehra, K. B., and Mukerji, B., Proteolytic system (plasma trypsin) in normal and various pathological conditions. Ind. med. Gaz., 1942, 77, 348.

21. Smith, O. W. and Smith, G. V., A fibrinolytic enzyme in menstruation and late pregnancy toxemia. Science, 1945, 102, 253.

22. McFarlane, R. G., Fibrinolysis following operation. Lancet, 1937, 1, 10.

23. Swift, H. F., Wilson, A. T., and Lancefield, R. C., Typing group A hemolytic streptococci by $M$ precipitin reactions in capillary pipettes. J. Exper. Med., 1943, 78, 127.

24. Cohn, E. J., Oncley, J. L., Strong, L. E., Hughes, W. L., Jr., and Armstrong, S. H., Jr, The characterization of the protein fractions of human plasma. J. Clin. Invest., 1944, 23, 417.
25. Folin, O., and Ciocalteu, V., On tyrosine and tryptophane determinations in proteins. J. Biol. Chem., 1927, 73, 627.

26. Anson, M. L., The estimation of pepsin, trypsin, papain, and cathepsin with hemoglobin. J. Gen. Physiol, 1938, 22, 79.

27. Tillett, W. S., Edwards, L. B., and Garner, R. L., Fibrinolytic activity of hemolytic streptococci; the development of resistance to fibrinolysis following acute hemolytic streptococcus infections. J. Clin. Invest., 1934, 13, 47.

28. Tillett, W. S., The fibrinolytic activity of hemolytic streptococci. Bact. Rev., 1938, 2, 161.

29. Mote, J. R., and Jones, T. D., Studies of hemolytic streptococcal antibodies in control groups, rheumatic fever and rheumatoid arthritis. J. Immunol., 1941, 41, 61 .

30. Kaplan, M. H., Studies of streptococcal fibrinolysis. II. The inhibition of streptococcal fibrinolysis by antifibrinolysin and antiprotease. J. Clin. Invest., 1946, 25, 337.

31. Kaplan, M. H. and the Commission on Acute Respiratory Diseases, Studies of streptococcal fibrinolysis. III. A quantitative method for the estimation of serum antifibrinolysin. J. Clin. Invest., 1946, 25, 347. 